\title{
First record and establishment of Tuberocephalus (Trichosiphoniella) tianmushanensis Zang, (Hemiptera Aphididae) on ornamental cherry trees in Italy
}

\author{
G. Pellizzari, G. Frigimelica \\ Dipartimento di Agronomia, Animali, Alimenti, Risorse Naturali e Ambiente (DAFNAE), \\ Università di Padova, Italy
}

\begin{abstract}
The occurrence of the Asiatic aphid Tuberocephalus (Trichosiphoniella) tianmushanensis Zang, (=Tuberocephalus (Trichosiphoniella) higansakurae hainnevilleae Remaudière and Sorin) (Hemiptera Aphididae) in Italy is reported. The species was first detected inside leaf galls of Prunus subhirtella cv. pendula trees growing outdoors at the University Botanical Garden of Padua (Italy). Further investigations demonstrated that the species is present in plant nurseries in the Veneto region. So far this species was considered eradicated in Europe, after its first incursion in France in 1993.
\end{abstract}

\section{Introduction}

Botanic gardens offer a unique opportunity in detecting alien insects and mites, due to the presence of exotic plants introduced from differ-

Correspondence: Giuseppina Pellizzari, Dipartimento di Agronomia, Animali, Alimenti, Risorse Naturali e Ambiente (DAFNAE), Università di Padova, viale dell'Università 16, 35020 Legnaro (PD), Italy.

E-mail: giuseppina.pellizzari@unipd.it

Key words: Tuberocephalus spp, Prunus subhirtella cv. pendula, Weeping Higan Cherry, leaf galls, alien insects.

Acknowledgements: the authors are grateful to Prof. S. Barbagallo, University of Catania, Italy, for kindly confirming the identification of the species, for tracing fundamental references and for his valuable remarks and suggestions. Many thanks to Danièle Matile-Ferrero, Muséum National d'Histoire Naturelle - Entomologie, Paris, France for her help on providing reprints by $\mathrm{G}$. Remaudière and $\mathrm{M}$. Sorin.

Received for publication: 31 July 2013.

Revision received: 19 November 2013.

Accepted for publication: 19 November 2013.

(C) Copyright G. Pellizzari and G. Frigimelica, 2014

Licensee PAGEPress, Italy

Journal of Entomological and Acarological Research 2014; 46:1855

doi:10.4081/jear.2014.1855

This article is distributed under the terms of the Creative Commons Attribution Noncommercial License (by-nc 3.0) which permits any noncommercial use, distribution, and reproduction in any medium, provided the original author(s) and source are credited. ent areas of the world. The plants growing in the historical Botanical Garden of Padua (Italy), established in 1545, are regularly monitored in order to control fungal diseases and phytophagous insects and mites. These regular surveys have led to the discovery of several alien insects and mites, previously unrecorded in Europe and, surprisingly, also new for science (i.e. Trochiscococcus speciosus (De Lotto), Balanococcus kwoni Pellizzari et Danzig (Hemiptera, Pseudococcidae), Aleuroclava aucubae (Kuwana) (Hemiptera, Aleyrodidae), Ambrosiodomus rubricollis (Eichhoff) (Coleoptera, Scolytidae), Stigmaeopsis nanjingensis (Ma et Yuan) (Acari, Tetranychidae) (Williams \& Pellizzari, 1997; Pellizzari \& Simala, 2007; Pellizzari \& Danzig, 2007; Pellizzari \& Duso, 2009; Faccoli et al., 2009; Pellizzari et al., 2010).

On May 30, 2012 several red-pinkish galls were observed on the leaves of two Prunus subhirtella cv. pendula trees (Rosaceae) (Weeping Higan Cherry), about 40 years old, growing in the University Botanical Garden of Padua (Figure 1). The galls were formed on a portion of the leaf edge, rolled towards the underside and were almost evenly distributed on the tree canopy.

At the collecting date, the following morphs were present inside the galls: few nymphs, nymphs with wing pads, alatae fundatrigeniae (emigrants) (Figure 2).

The species was identified as Tuberocephalus (Trichosiphoniella) higansakurae hainnevilleae Remaudière and Sorin, 1993, (Hemiptera Aphididae), an Asiatic heteroecious species known so far in Japan and China (Su et al., 2010) and not yet recorded in Italy.

The first incidental introduction to Europe of an oriental aphid of the genus Tuberocephalus Shinji occurred in 1991 in France [Remaudière \& Sorin (1993), these authors identified the species as T. higansakurae (Monzen, 1927) and described the new subspecies hainnevilleae Remaudiére et Sorin].

A few years later the same authors (Sorin \& Remaudière, 1998) pointed out the possibility that $T$. higansakurae hainnevilleae, could be a synonym of $T$. (Trichosiphoniella) tianmushanensis Zang, 1980, due to their similarity. Su et al. (2010) compared the types of $T$. (Trichosiphoniella) tianmushanensis with the original description and drawings of T. (Trichosiphoniella) higansakurae hainnevilleae by Remaudière and Sorin (1993) and confirmed the possible synonymy of the two species. The synonymy of the two species is apparently accepted in the Aphid Species File Data Base (Favret, 2013).

According to Remaudière and Sorin (1993), in Autumn 1990, a few thousands of $P$. subhirtella pendula seedlings were imported from Japan to France. In the following spring the trees were strongly infested by aphids forming galls on the leaves. The infested leaves were eliminated and all the young trees treated with an insecticide. An attempt to transfer emigrants to Artemisia vulgaris, the secondary host plant, under controlled conditions, in order to obtain alienicolae (exules) failed. No galls were observed on the trees in the following spring, so that it was 
assumed that the species was eradicated (Remaudière and Sorin, 1993; Sorin and Remaudière, 1998). No other records of Tuberocephalus species have been recorded in Europe since (Coeur d'Acier et al., 2010).

\section{Biological notes on the genus Tuberocephalus}

About twelve Tuberocephalus species are known in East Asia (Japan, Korea, China, Pakistan, India, Malaysia and Eastern Russia) galling the leaves of Prunus trees, the primary host (Sorin \& Remaudière, 1998; Blackman \& Eastop, 1994, 2006; Holman, 2009). The secondary host plants, when known, are mostly Asteraceae of the genus Artemisia. The alienicolae of species belonging to the genus Tuberocephalus s. str. colonize the underside of Artemisia leaves, whereas species of the subgenus Trichosiphoniella colonize Artemisia roots or stolons.

The life-cycle of the Tuberocephalus species is quite similar and is known for some species, taking into account that they all overwinter in the egg stage, near the buds of Prunus trees.

The fundatrix of T. artemisiae Shinij hatches in late March or late April and forms a gall on the leaf. The alatae fundatrigeniae migrate to the secondary host, $A$. vulgaris var. indica, in June. The alienicolae are apterous and feed on the underside of the leaves. The gynoparae appear in October and migrate to the primary host. Males return to the primary host in November (Sorin, 1994).

T. sakurae (Matsumura) has a similar cycle, but the migration to $A$. vulgaris var. indica lasts from May to August; moreover the apterous alienicolae feed on young shoots in the ground (Sorin, 1993).

The fundatrix of T. misakurae Moritsu \& Hamasaki hatches in late March. Each fundatrix produces many nymphs; apterous fundatrigeniae are rather rare, most of nymphs evolve into alates (Moritsu \& Hamasaki, 1983). In May the alatae fundatrigeniae migrate to the secondary host Dendranthema sinensis (=Chrysanthemum morifolium). The apterous alienicolae feed on thin lateral roots through summer. Gynoparae appear from late October to early December and migrate to the primary host; the males migrate from mid November to early December (Sorin \& Imura, 1996).

\section{Observations on $T$. (Trichosiphoniella) tianmushanensis Zang}

The primary host of $T$. (Trichosiphoniella) tianmushanensis Zang are Prunus sp., $P$. donarium spontanea, $P$. itosakurae, $P$. pseudocerasus, $P$. pendula, $P$. subhirtella var. pendula, whereas the secondary host are $A$. vulgaris var. indica and Artemisia spp. (Sorin \& Remaudière, 1998; Su et al., 2010).

According to Sorin and Remaudière (1998), this species forms two types of galls on Prunus leaves. The fundatrix hatches in late March, and produces a bag-shaped gall on the edge of tender leaves. The adult fundatrices appear in May and give birth to apterous and alatae fundatrigeniae. The alatae migrate to the secondary host whereas the apterous fundatrigeniae also produce a tube-like gall, curled and wrinkled, on the leaf edge and give birth to nymphs that become alatae emigrants in late May-June. On Artemisia plants they give birth to nymphs that get into the ground and feed on the young shoots of the host plant. The alatae gynoparae emerge from late October to mid November and return to the primary host to produce the oviparous female. The overwintering eggs are laid near the buds.

In the Botanical Garden of Padua, the galls of T. (Trichosiphoniella) tianmushanensis Zang were first detected on May 30, 2012. At this date the most numerous morphs inside the galls were fundatrigeniae nymphs with wing pads and alatae fundatrigeniae (emigrants). During the first week of June the emigrants progressively left the galls and by June 11 all the galls resulted empty. After the first detection of the aphid, investigations were carried out from August to October 2012 on P. subhirtella pendula trees growing in public parks and avenues of the town of Padua and in plant nurseries, located in a large area, eastern of the town; occasional observations occurred wherever P. subhirtella pendula trees were traced. Besides the Botanical Garden of Padua, galled leaves were detected in a plant nursery at Saonara (Padua district) on an old tree growing outdoors and on several potted trees grafted with scions taken from the old plant. Another infested tree was detected in a garden at Rossano Veneto (Vicenza district), about $40 \mathrm{~km}$ far away from the first detected infested trees in Padua.

As above reported, the secondary hosts of Tuberocephalus species, when known, are mostly Artemisia plants. In the Botanical Garden of Padua the following species of Artemisia are regularly cultivated: $A$. abrotanum, A. absinthium, A. annua, A. atrata, A. dracunculus, A. ponti$c a, A$. vulgaris. In the attempt to find the alienicolae on the secondary host, roots and stolons of the above recorded Artemisia species were checked on June $18^{\text {th }}$, on July $16^{\text {th }}$ and on August $18^{\text {th }}$ without any result. Artemisia vulgaris is a very common Palaearctic perennial plant that grows on weedy and uncultivated areas, such as waste places, roadsides and riversides. Many Artemisia vulgaris plants were growing in the surroundings of galled $P$. hirsutella pendula trees detected in the plant nursery and in other locations. In August samples of A. vulgaris roots and stolons were collected and checked, but no aphids were observed. In

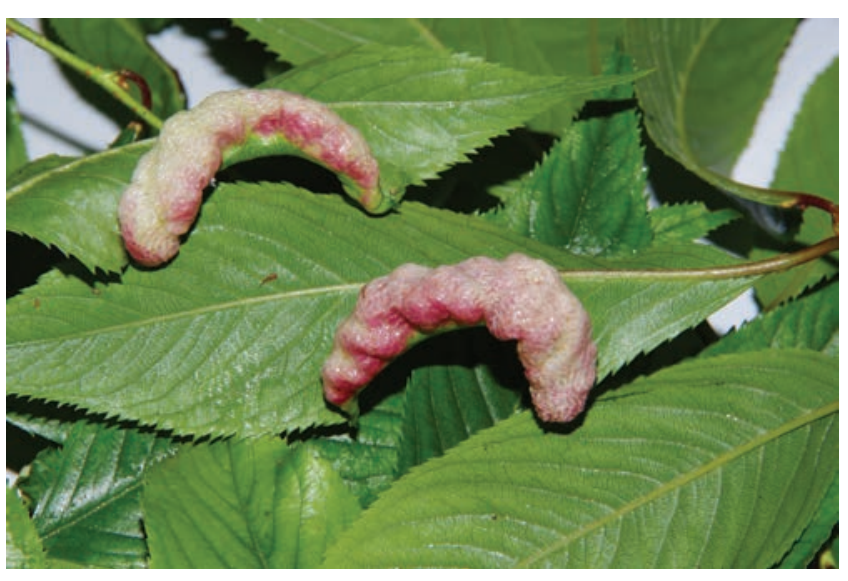

Figure 1. Galls of Tuberocephalus (Trichosiphoniella) tianmushanensis on leaf of Prunus subbirtella pendula.

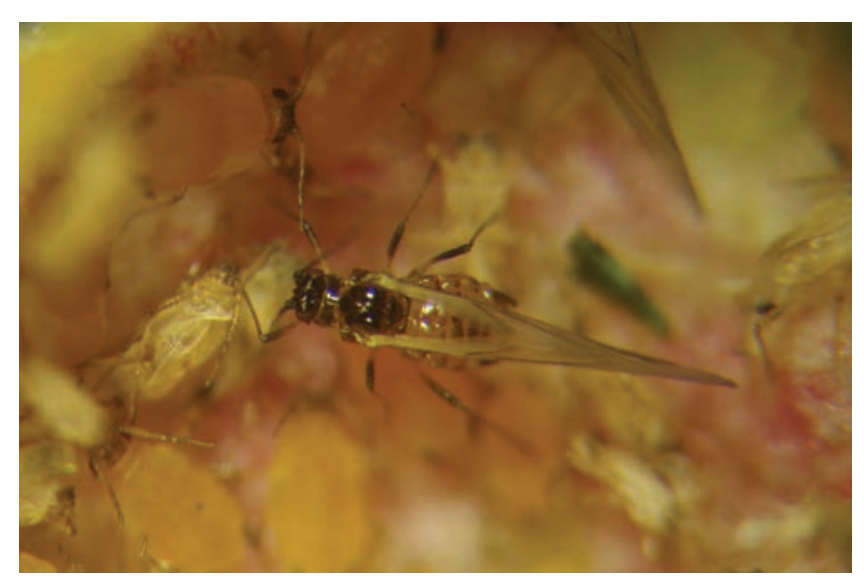

Figure 2. Alatae fundatrigeniae (emigrant). 


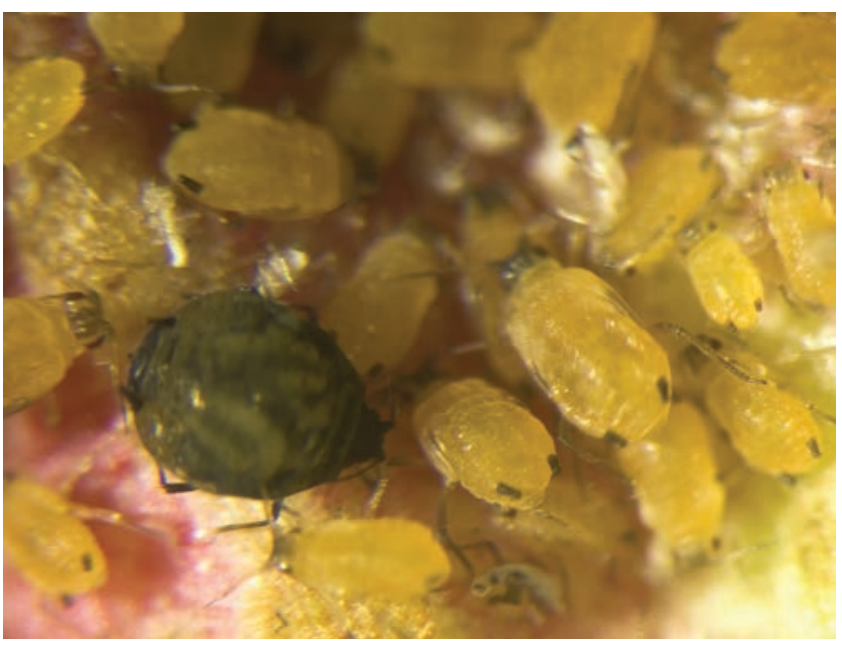

Figure 3. Dark fundatrix inside a gall, with yellow nymphs.

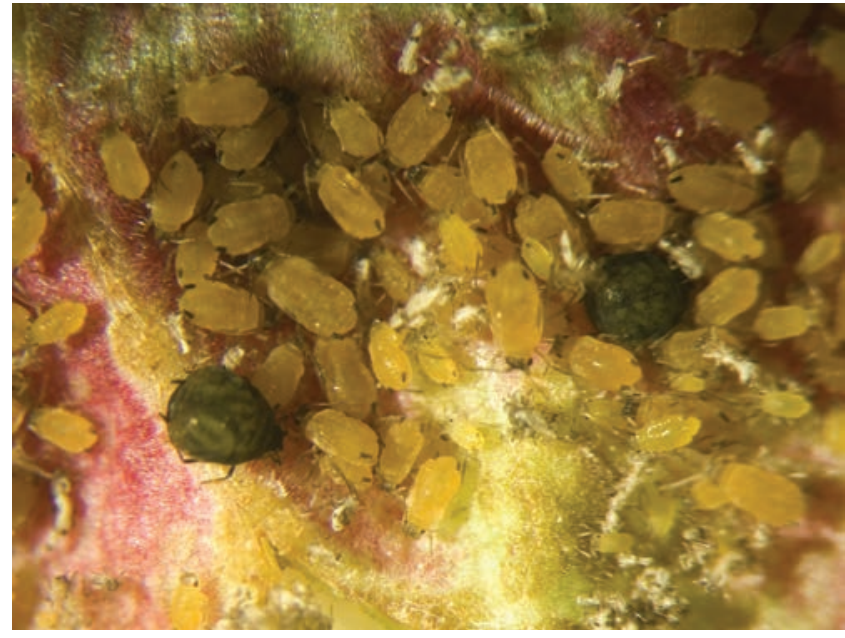

Figure 4. Two fundatrices in the same gall, with nymphs.
October 2012 sampling of Prunus subhirtella twigs were collected and checked but no overwintering eggs were detected on, whereas several overwintering eggs were definitely found in February 2013.

In May 2013 many galled leaves with dark fundatrices inside (Figures 3 and 4) were observed again on the same P. subhirtella cv. pendula trees growing both in the Botanical Garden and in the nursery.

These records clearly indicate that many overwintering eggs were laid by oviparous females in the previous autumn and suggest that the aphid is established in the Veneto region.

\section{References}

BLACKMAN R.L., EASTOP V.F., 1994 - Aphids on the world's trees. An identification and Information Guide. - CAB International, Wallingford: 986.

BLACKMAN R.L., EASTOP V.F., 2006 - Aphids on the world's herbaceous plants and shrubs. Vol. 1. Host lists and keys; vol. 2. The Aphids. Wiley \& Sons, Ltd, Hoboken: 1439.

COEUR D'ACIER A., PÉREZ HIDALGO N., PETROVI-OBRADOVI 0., 2010 - Chapter 9.2: Aphids (Hemiptera, Aphididae). In: ROQUES A., KENIS M., LEES D., LOPEZ-VAAMONDE C., RABITSCH W., RASPLUS J.Y., ROY D.B. (Eds), Alien terrestrial Arthropods of Europe BioRisks. Vol. 4. - Pensoft Publishers, Sofia: 435-474.

FACCOLI M., FRIGIMELICA G., MORI N., TOFFOLO PETRUCCO E., VETTORAZZO M., SIMONATO M., 2009 - First record of Ambrosiodmus (Hopkins, 1915) (Coleoptera: Curculionidae, Scolytinae) in Europe. - Zootaxa 2303: 57-60.

FAVRET C., 2013 - Aphid Species File. Version 5.0/5.0. Available from: http://Aphid.SpeciesFile.org Accessed: March 2013.

HOLMAN J., 2009 - Host plant catalog of Aphids. Palaearctic region. Springer, Berlin: 1216.

MORITSU M., HAMASAKI S., 1983 - A new gall forming aphid of the genus Tuberocephalus Shinji (Homoptera, Aphididae) on cherry trees in Japan. - Kontyû, Tokyo 51: 221-227.

PELLIZZARI G., DANZIG E., 2007 - The bamboo mealybugs Balanococcus kwoni n.sp. and Palmicultor lumpurensis (Takahashi) (Hemiptera, Pseudococcidae). - Zootaxa 1583: 65-68.

PELLIZZARI G., DUSO C., 2009 - Occurrence of Stigmaeopsis nanjingensis in Europe. - Bull. Insectol. 62: 149-151.

PELLIZZARI G., SIMALA M., 2007 - First record of Aleuroclava guyavae (Takahashi, 1932) (Hemiptera, Aleyrodidae) in Europe. - Boll. Zool. Agr. Bachic. Ser. II 39: 91-95.

PELLIZZARI G., CASSINA G., CAPPELLETTI E.M., FRIGIMELICA G., 2010 - The botanical Garden of Padua (Italy): a reservoir of alien insects and mites, (poster abstract). - Book of Abstracts, $4^{\text {th }}$ Global botanic Gardens Congress, $13^{\text {th }}-18^{\text {th }}$ June 2010, Dublin, Ireland: 132.

REMAUDIÈRE G., SORIN M., 1993 - Two new aphids of the genus Tuberocephalus Shinji (Homoptera, Aphididae). Japan. - J. Entomol. 61: 683-690.

SORIN M., 1993 - The life cycle of Japanese species of Tuberocephalus. In: KINDLMAN P., DIXON A.F. (Eds), Critical issues in aphid biology. - Proc. $4^{\text {th }}$ Int. Symp. on Aphids, Ceske Budejovice: 123-126.

SORIN M., 1994 - Life history of Tuberocephalus artemisiae (Aphididae, Homoptera). - Spec. Bull. Trans. Essa Entomol. Soc. 2: 109-112.

SORIN M., IMURA H., 1996 - Life history of Tuberocephalus misakurae Moritsu et Hamasaki (Homoptera Aphididae). - Rostria 45: 1-6.

SORIN M., REMAUDIÈRE G., 1998 - A review of the genus Tuberocephalus Shinji (Hemiptera, Aphididae) with description of two new species from Pakistan and Japan. - Bull. Faculty Literature Kogakkan Univ. 37: 91-146.

SU X.M., JIANG L.T., QIAO G.X., 2010 - Tuberocephalus (Hemiptera: Aphididae) from China with description of a new species. Oriental Insects 44: 157-191.

WILLIAMS D.J., PELLIZZARI G., 1997 - Two species of mealybugs (Homoptera Pseudococcidae) on the roots of Aloaceae in greenhouses in England and Italy. - Boll. Zool. Agr. Bachic. Ser. II 29: 157-166. 